TEME, г. XLII, бр. 4, октобар - децембар 2018, стр. 1125-1140

Оригинални научни рад

DOI: $10.22190 /$ TEME1804125A

Примљено: 5. 9. 2017.

Ревидирана верзија: 24. 12. 2017.

Одобрено за штампу: 12. 6. 2018.

\author{
UDK 622.12(497.11 Dubočica)"15"
}

\title{
MINING IN DUBOČICA IN THE 16th CENTURY*
}

\author{
Dragana Amedoski, Vladeta Petrović \\ Institute of History Belgrade, Belgrade, Serbia \\ dragana.amedoski@iib.ac.rs
}

\begin{abstract}
The paper deals with the Prloš mine, which was located in the area of modern day mine Lece. Around the mine, which was administratively a part of the nâhiye of Dubočica or Kruševac Sancak, a workers' hâss was formed and in addition the mine was given the status of an independent mukâta ' $a$, which indicates that the Prloš was worthy of attention and investment for the Ottoman administration. The mine was under the financial control of the Belgrade Supervisory Authority (nezâret). Special attention was paid to the position of the mine itself, as well as leases, who were the tenants, what were the amounts of lease and how much the lease lasted. The paper is based on new and previously unused sources of Ottoman provenance.
\end{abstract}

Key words: $\quad$ Ottoman Empire, Prloš, mine, hâss, lease, 16th century, Lece.

\section{РУДАРСТВО У ДУБОЧИЦИ У 16. ВЕКУ}

\begin{abstract}
Апстракт
Предмет рада је рудник Прлош, који се налазио у рејону данашњег рудника Леце. Око рудника који је у административном погледу био у саставу нахије Дубочица, односно Крушевачког санџака, формиран је раднички хас, а уз то му је дат и статус самосталне мукате, што говори да је Прлош за османску администрацију био вредан пажње и улагања. Рудник је био под финансијским надзором Београдског надзорништва (тур. nezâret). Посебна пажња посвећена је убикацији самог рудника, као и закупима, ко су били закупци, колики су били износи закупа и колико је закуп трајао. Рад је заснован на новим и до сада некоришћеним изворима османске провенијенције.
\end{abstract}

Кључне речи: Османско царство, Прлош, рудник, хас, закуп, 16. век, Леце.

\footnotetext{
* This arcticle is the result of the projects No. 177030 and 47025 of the Ministry of Education, Science and Technological Development of the Republic of Serbia.
} 
The territory of today's Serbia is an area with an extremely long tradition of mining. Some sites had continuity in mining activity during prehistory and ancient period (Jovanović, 2012, 212; Jovanović, 1988, 512; Jovanović, Minić, Mrkobrad, 1987, 49). With the establishment of the first Saxon coal mining settlements and the opening of new ones and the restoration of old mining activities, the rise of Serbian medieval mining begins. ${ }^{1}$ Based on the previous studies, it is not possible to say with certainty what the relationship between the number of newly opened mines and ancient mines in which Saxons restored the production is, because all the medieval mines in the area of today's Serbia are located on ore deposits known and used in the ancient period (Ćirković, Kovačević-Kojić, Ćuk, 2002, 50).

Thanks to the mineral resources of the Dinaric-Serbian-Macedonian metallogenetic province, big mining towns of Novo Brdo, Srebrenica and Rudnik developed. In mountainous areas, often inaccessible and remote from the main communications, a number of smaller marketplaces were formed whose economic base was mining exploitation and metal trading. Such are the marketplaces of Trepča, Janjevo, Plana, Zaplana, Koporić, Ostatija, which developed thanks to the mining of non-ferrous and precious metals. ${ }^{2}$

Medieval mining production in Serbia reached its peak in the first half of the $15^{\text {th }}$ century when a large part of the silver in Western Europe came from the mines of Serbia and Bosnia (Ćirković, Kovačević-Kojić, Ćuk, 2002, 118; Blanchard, 2005, 1021). Thanks to the production and processing of metals and their export, huge revenues from regal rights on ores, purified metal, money mints and metal trading poured into the treasuries of Serbian and Bosnian rulers (Ćirković, Kovačević-Kojić, Ćuk, 2002, 123). Only the revenues of Despot Đurađ Branković from the mine Novo Brdo amounted up to 200,000 ducats (Ćirković, 1997, 107).

It is these rich gold and silver mines and important trading centers that became the primary goals of Port's invading plans. Starting from the times of Murat I (1359-1389) the Ottomans took control over individual rich mines in Serbia and Bosnia (Neşri, 1987, 212). ${ }^{3}$ Mehmet the Conqueror (1451-1481), at the time of the establishment of the Empire, understood the importance of mines as a source of state revenues. Already

\footnotetext{
${ }^{1}$ The Roman province of Moesia, which included a large part of today's Serbia, was known as a mining province. Traces of Roman mining and metallurgical activities are still visible today on Kosmaj, Avala, Rudnik, Kopaonik and in Eastern Serbia (Dušanić, 2003, 255, 259-260).

${ }^{2}$ More on Serbian marketplaces in Kopaonik mining area during the Middle Ages see: Božanić 2007; Petrović 2014, 290-301; Zarković 2017a, 238-242, 256-258; Zarković $2017 \mathrm{~b}$.

${ }^{3}$ Thus, a report on Turkish military power, institutions, expenditures and revenues from 1378, contains data that the Sultan's income from the mine amounted to 120,000 Venetian ducats (Ćirković, 1997, 107).
} 
in the first decade of his rule, from 1454 to 1464 , he frequently tried to establish permanent control over rich mining areas, which he ultimately succeeded (İnalc1k, 2000, 97).

After the Ottoman conquest, there were significant changes in the economic life of the Balkan region, which were particularly pronounced in mining. Ottoman sultans precisely regulated mining by written laws (kânûns), which testifies that mining was an issue of great importance for the Empire. (Spaho, 1913, 133-194; Refik, 1931; Beldiceanu, 1964; Rizaj, 1968, 51-57; Bojanić, 1974, 24-25; Akgündüz, 1990, 360-369, 376-379, 416-421, 443-457, 479-490, 533-593). Within the framework of the Ottoman economic system, the production and trading of metals were organized in a completely different way. The goal of the Ottomans was to maximize the exploitation of these mines, in order to meet their needs for precious metals, iron and lead (İnalc1k, 2000, 97). These changes were primarily reflected in the manner of control of income from mining and restrictions on free trade, including export of metals and ores (Pamuk, 2000, 44-45; Popović, 1994, 576).

The significance of the mineral wealth of the newly conquered areas led to, after the initial crisis that was the result of warfare, continued development of the old mining centers in Serbia and other European regions of the Ottoman Empire. In the first half of the $16^{\text {th }}$ Century, the Ottoman authorities restored activities in the most important mining centers in Rumelia, Novo Brdo, Rudnik, Kratovo, Siderokapsa, Srebrenica and Zaplana, which worked at full capacity (İnalc1k, 2005, 161). Also, new mines are opened, such as Majdanpek, Kučajna and Bah in Smederevo Sancak, or Ćelušnica in Berkovac kazâ and Modava in today's Romania (Katić, 2005b, 47).

Mines, like other natural resources, belonged to the Sultan's hâsses. In the 1480 's, Port took energetic measures to stimulate the profitability of production in them. The efforts of Bayezid II (1481-1512) who abandoned his father Mehmet II's conquest policy and turned to the economic empowerment of the Empire, as well as his commitment to the introduction of order in mining production and the harmonization of the mining legislation, had results (Ćirković, Kovačević-Kojić, Ćuk, 2002,146-149, 152-157). He also adopted the first Ottoman legal regulations related to mining, which were later improved by Suleiman the Magnificent (15201566) (Akgündüz, 1990, 360-370). They were based on the principles of the Law on Mines of Despot Stefan Lazarević. The aim of these laws was to improve the internal organization of mining, as well as to get the local population interested in working in mines. One of the goals was also to improve the position of the miners, that is, to reduce the arbitrariness of the emîns, whose work was placed under the control of Ottoman kâdîs (Popović, 1994, 578; Ćirković, Kovačević-Kojić, Ćuk, 2002, 174-175). 
With the expansion of Ottoman rule in the southern areas of the Serbian medieval state, extremely rich mining region of Kopaonik came under its control. One part of it belonged administratively to the Kruševac Sancak. This is related to three mining regions - region of Plana, Zaplana and Slišane (Jablanica) andesite massif, with the remains of old mining, which indicate a developed medieval mining. ${ }^{4}$

Mining activity continued after the Ottoman conquest in the region of Plana and Zaplana (TD 55, s. 2). ${ }^{5}$ Central mining settlements of Plana and Zaplana at the time were marketplaces with the predominantly Serbian local population. In addition to the local population, Ottoman censuses record a number of Dubrovnik and Arbanasi people, as well as Gypsies (Vasić, 1979, 33-34). Until the census of 1530, Plana had become the seat of kazâ that also included Zaplana mine (167 numaralı muhâsebe-i vilâyet- Rûm-ili defteri (937/1530), 2004, 417-418).

In the Ottoman era, in the territory of the Kruševac Sancak, in addition to Plana and Zaplana, another mine was operational, which was not recorded in domestic historiography at all (Zirojević, 1983, 215, 256). Administratively, this mine belonged to the nâhiye of Dubočica, more precisely Medveđa. ${ }^{6}$ Generally, the nâhiye of Dubočica was first in the

\footnotetext{
${ }^{4}$ Plana is a medieval mining settlement, a marketplace and a center of a mining region. Its mines produced gold in powder and in glam silver, silver, lead, copper and usually and refined iron. About $36.2 \%$ of all by now verified smelters and $22.8 \%$ of old mines on Kopaonik have been reclaimed around Plana. According to written accounts, mining in the area of Plana lasted from the mid-14 ${ }^{\text {th }}$ century until the First Serbian Uprising. Judging by the length of the underground mining works, the exploitation of ores had to begin in the $13^{\text {th }}$ century. Plana, Kopaonik, Beograd 2015, 147-148 (V. Petrović) with older literature.

Zaplanina is a medieval settlement and a center of a mining region. This name was once used for the entire area on the eastern slopes of Kopaonik, just below Suvo Rudište. Now, Zaplanina refers only to the headwaters of the Đerekarska River, between Vojetin and Bećirovac.

Old mines were located at altitudes of over 1,200 meters (occasionally over 1,700) and smelters at 1,000 to 1,700 meters. In the entire mining region, about 2,000 old mining shafts and 45 slag deposits have been reclaimed, and this does not yet show the actual extent of mining work in this region. As the terrain here is very steep, the minerals were here searched for from deep valleys, and from them by means of lateral galleries. The presence of such works on the surface is almost imperceptible, although under the ground there are real mazes of corridors, trenches and mining shafts. Zaplanina, Kopaonik, 67-68 (V. Petrović) with older literature.

${ }^{5}$ The oldest known census of Kruševac Sancak dates back to the $15^{\text {th }}$ century (14441446). However, the part of the census listing Sultan's hâss, that is, Plana and Zaplana, is lost (Zirojević, Eren, 1968, 377-416).

${ }^{6}$ All these settlements belonged administratively to Dubočica. However, the sources indicate that they belong to Medveđa, probably because it was the largest marketplace in the part of the nâhiye of Dubočica where there was the workers' hâss of Prloš mine, and later the seat of kazâ.
} 
court jurisdiction of the kazâ of Niš, and later the kazâ of Leskovac and Medveđa. At the same time, this affair was under the financial supervision of the Belgrade Supervisory Authority. ${ }^{7}$

Because of the imprecision of the Arabic script, namely failure to record short vocals in the writing of this name in the sources that were available to us, we cannot read this toponym (برلوش). Therefore, its name is uncertain, but some of the possible variants of this name are Prloš, Perloš, Pirloš, Preloš, Preluš, Prluš. All of these variants can be related to the terms of prline, prla, prlače, prlovi, which denote oxidized, sometimes kaolinized surfaces in a relief that are related to the offshoots of sulfide or oxide ores. ${ }^{8}$

The existence of Prloš mines is explicitly indicated in numerous historical sources (BOA, MAD 654, 656, 6148; BOA, D.BŞM 102, etc). The mine itself had the same name as a village, in the immediate vicinity of which it was probably located, and which is today not known under that name. However, no toponym has been retained until present day that would point us to the place of the mine and village. This mine was not mentioned even by travel writers, which leads us to the conclusion that it was not located on one of the nearby main roads. ${ }^{9}$

Although several censuses have been preserved for Kruševac Sancak and the nâhiye of Dubočica, the mine is only mentioned in the census of 1536. (BOA, TD 179, s. 32-33). At one point even the emin of this mine was mentioned, to whom the revenues from sheep herding and pens of the village of Gornje Gazdare belonged (BOA, TD 179, s. 24).

In the $15^{\text {th }}$ and early $16^{\text {th }}$ centuries, it was common in the Ottoman Empire that several surrounding villages are given to the mining sites that were given the status of a mine. Larger mines were then assigned the villages

\footnotetext{
${ }^{7}$ In the first half of the 16th century, the nâhiye of Dubočica was under the jurisdiction of the kâdî of Niš. Changes in the distribution of judicial power occurred most probably in 1566 when Kruševac Sancak was included in the Timisoara eyalet. At that time, Leskovac and Medveđa became seats of the kazâ, among others.

In the Ottoman Empire there was a major mining supervision authority (nezâret) and local supervision authorities subordinated to it. The mines in the territory of today's Serbia were under the control of Belgrade and Skopje supervision authority (Katić, 2001, 11).

${ }^{8}$ On Rudnik - Prline, Prlovi, Mala and Velika Prlina, Delalića Prlina, Prlinski Šturac. Prlo, Bela Prla and Veliko Prlo are sites on Lipovica mountain, between the Ibar and Raška rivers. Žuta Prla is deposit of lead-zinc ore between Jelakce and Koporić. Prline is the mine near Janjevo. Prlina is the place in the village of Dvorska, near the hamlet of Janjići (Simić, 1974, 173).

Among numerous toponyms related to the oxidized and kaolinized surfaces of the relief, the toponym of Prlina stands out, near Medveđa. See the map of Military Geography Institute 1:25 000, Leskovac 1-3.

${ }^{9}$ The roads that crossed this area were those that led via Medveđa from Novo Brdo to Leskovac, Niš and Priština (Škrivanić, 1974, 95).
} 
of the entire mining region, which, united in the hâss, had immunity status (Katić, Katić, 2010, 200). It is obvious that the Prloš mine was quite significant at the beginning of the $16^{\text {th }}$ century, because a workers' hâss was established around it (iş̧̧i hâss).

The normal operation of every mine, including the mines in the Kruševac Sancak, Plana, Zaplana and Prloš, implied, among other things, well-populated surrounding area whose population would supply food to the miners (Handžić, 1974, 155-162; idem, 1978, 30-31, 33).

It was necessary that there is permanently settled population in the vicinity of mines, who would, in addition to their basic activities, also perform various activities related to mining. Because of this, imperial hâsses with mines included several villages assigned to mines to provide labor for auxiliary mining operations, burning of charcoal, transport of ores, providing transportation (Bojanić, 1985, 78).

Residents of workers' hâsses were also freed from extraordinary taxes and conventional duties. ${ }^{10}$ They had work duties, mostly related to the production and delivery of charcoal and timber, as well as to various auxiliary services in pits and smelters. For this reason, they also enjoyed significant tax incentives (Katić, Katić, 2010, 205).

According to the census from 1599/1600, 22 villages and one monastery belonged to the hâss of the Prloš mine: Medveđa, Oraždine, Orač, Drence, G. Milanica, Vrtop, G. Slišani, Gajtan, Drenovce, Bradašor, Selce, G. Gozdari, Ludopare, D. Slišani, D: Gozdari, Islevci, Drenov dol, Ravnište, monastery St. Archangel in Medveđa, Crvodik, Prloš, Radevce. The total income from these villages was 92.646 akches (BOA, TD 664, s. 21).

Some of these villages were also recorded in the trading book of Mihailo Lukarević from Dubrovnik, who operated in Novo Brdo in the 1430's. Thus, in the area that was called Podgor in the Middle Ages, and which included the slopes of Golak Mountain, the villages of Slisani, Orach and Hobrasdena are also mentioned. Lukarević also mentions Medveđa, but he does not mention that it is near Podgora (Dinić, 2003, 591, 594-595).

The Prloš mine was most probably located within the limits of its hâss, whose villages, just like the village of Prloš, mostly belonged to Medveđa. Therefore, it should be looked for in the area between the mountains Radan, Majdan and Rasovača. As active mine of lead and zink

\footnotetext{
${ }^{10}$ There is a possibility that part of the population was not recorded in the censuses of the villages that were assigned to the hâss. This is primarily related to experts who were not involved in agriculture even as a secondary activity, and owned property there that was not the subject of tax.
} 
Lece is coated in this area today, ${ }^{11}$ we can connect the old Prloš mine with the spacious mining region that stretches from Novo Brdo to Đavolja varoš (Simić, 1951, 239).

Deposits of lead, zinc and gold of Lece are located within the large Slišane (Jablanica) andesite massif. The length of this massif is about 50 kilometers, and the largest width is up to 25 kilometers, while its surface is 750 square kilometers. Towards the northwest, it reaches almost to Kuršumlija, and to the south to Kitka (Velja Glava). ${ }^{12}$ Within this mining region, there are numerous traces of old mining, which are especially grouped around Tulari, Lece and Đavolja varoš (Simić, 1951, 239).

Remains from the Early Byzantine period point to the economic importance of this area for one of the most significant Early Byzantine urban centers - the Empress' Town, in whose vicinity which lies the mining area of Lece. Particularly important are traces of mining activity from the pre-Roman, ancient and medieval periods registered in the wider area around the modern mine (Ivanišević, Bugarski, 2017, 58-59).

In the immediate vicinity of today's Lece mine there are the remains of old mines, almost without interruption, in the length of about 1.5 kilometers. More remains of mining can be found to the west of the mine on Majdan Mountain, which rises between the villages of Gajtan, Svinjište and Drenac. The main hallways are located on the territory of the villages of Gajtan and Drenac. As one of the neighborhoods of Drenac, a village belonging to the workers' hâss of the mine, named Majdan, it is possible that the old mine Prloš and the namesake village should be looked for in this area. ${ }^{13}$ In the neighboring district of Brajšor there are remains of the fortifications, while near the Majdanski stream there are pits about 2 meters in diameter, used by old miners for surface mining of ore. In the district of Vrtop remains of a circular building were found, with a diameter of 0.80 meters, with stone wall made of cut rubble, which was probably used for melting the ore. The mentioned remains of mining and smelting activities suggest the existence of a unique mining and metallurgical complex in the area of Drenac village (Jocić, 1999, 53).

\footnotetext{
${ }^{11}$ Lece is located $42 \mathrm{~km}$ to the west from Leskovac and $60 \mathrm{~km}$ to the southeast from Priština. Drenski, Majdanski and Vrelski streams form the Lecka River that empties in the Gazdarska River, and this one into Jablanica (Ilić,1984, 9).

${ }^{12}$ In the region of Lece, the formation of deposits and minerals of lead, zinc and gold is related to the tectonic-magmatic processes of the tertiary metallogenic era. Ore minerals are: pyrite, marcasite, sphalerite, chalcopyrite, enargite, galena, hematite..., and non-ore minerals are: carbonate, quartz, apatite and others. (Ilić, 1984, 9-10). Some of the remains of old mining works may refer to the exploitation of the deposits of amethyst and opal (Simić, 1951, 240).

${ }^{13}$ O. Zirojević links Prloš mine to the modern village of Majdan (Zirojević, 1983, $215,256)$
} 
In addition to the mentioned furnace in Drenac, traces of smelting activity are little preserved. Dross in immediate vicinity of the present mine is covered with mullock, while in the center of Lece, during the construction of flotation, one hill of the slag was shattered. Such a relationship between mining and smelting activity suggests that primarily gold-bearing ores in oxidation zone were excavated here. ${ }^{14}$ Melting of ores was only carried out in case of higher concentration of lead ores or when the iron ore was melted for the needs of the mine itself. Remains of such smelters were found on left bank of the Rudnički stream, about 1 kilometer from today's pit. ${ }^{15}$

In addition to the traces of ancient mining, numerous objects and inscriptions from the ancient period, as well as the remains of medieval fortification and sacral buildings testify about the continuity of the population of this area. They are also found in the already mentioned settlements of the workers' hâss of Prloš mine. ${ }^{16}$

In the villages of Prloš hâss, the usual re âya taxes were imposed, which suggests that the inhabitants of these villages did not have significant work obligations, which would be subject to tax incentives.

The inhabitants of the village on the hâss were Christians. There were also Muslims, but in a small number; in Medveđa, G. Slišani and several other villages. ${ }^{17}$ Their number was insignificant at the beginning of the $16^{\text {th }}$ Century. The share of Muslims of different ethnicities in the total number of taxpayers was about $1.25 \%$ and it reached about $10 \%$ in the seventh decade of the $16^{\text {th }}$ Century. In the 1570 's, Medveda and the village of G. Slišani had approximately the same number of Christian and Muslim households.

Throughout the century, the number of households in the Prloš village stagnated. From 1516 to 1536, the village had 16 households, and

\footnotetext{
${ }^{14}$ In the ancient and medieval period, they were mainly limited to the exploitation of parts of mining veins that were oxidized and which yielded coarse gold by crushing, milling and rinsing of ore (Simić, 1951, 239).

${ }^{15}$ Only one of the furnaces was better preserved. It was made of clay and had a shape of a barrel, about 1 meter in height and with a diameter of 65-70 centimeters. Below the furnace there were about 20 rungs, which lay as rails and were of the same material as the furnace (Ilić, 1984, 21-23).

${ }^{16}$ Thus, the traces of the Roman authority are visible in Lece, Gazdar, Pusti Šilov, Gajtan and Medveđa (Ilić, 1984, 12-13). Around this mining area there was a system of fortifications made of fortresses in Lece, Medveđa, Sijarina, Brajina, Vrabac and on Sokolov, Mrkonjski, Tupalski and Brajšorski Vis. Remains of churches were recorded in Lece (Vidovdanka and St. John), Kopran (the site Strugara and St. Prokopije), Drenac (Crkvina), Gazdar (St. Pantelejmon, Crkvina -Ivanović estate, Crkvina - Ranđelović estate) (Jocić, 1999, 50-54).

${ }^{17}$ In 1516, there were 15 Muslims. In 1530, only 4, 1536. 13, 5 converts, and around 1570, there were 60 Muslims, of which 14 new ones. (TD 55, s. 13, 167 numaralı muhâsebe- $i$ vilâyet- Rûm-ili defteri (937/1530), II, s. 431, TD 179, s. 21-37, TD 567, s. 10b-19a).
} 
in 1570 that number slightly increased to 17 (BOA, TD 55, s. 14; 167 numaralı muhâsebe-i vilâyet- Rûm-ili defteri (937/1530), II, s. 431; BOA, TD 179, s. 32-33; BOA, TD 567, s. 16). We assume that there were more inhabitants that lived here than registered in the census, given that in mining places a large number of people enjoyed tax privileges and on that basis were not recorded in the censuses.

On the other hand, in the villages of Prloš hâss, a marked demographic decline occurred. The greatest demographic changes took place in the period from 1530 to 1536 , when the total population decreased by $28.6 \%$, in only six years. The total decline of the population recorded from 1516 to the 1570 's was $47.1 \%$. Although we have very little data on the exploitation of this mine, we could also link the loss of population with the possible decline in production in the mine. We see a similar situation in the mines Plana and Zaplana, which also recorded a decline in the number of people between the 1530's and the 1570's. The noted changes are related to crisis in the Balkan mining that occurred after mid-1520's and whose main causes were frequent and long-lasting outbreaks of plague and migrations caused by the great demand for the abandoned land in the newly conquered areas of Southern Hungary (Katić, 2008, 142, 145).

Due to the crisis that continued in the 1530's, in 1536, Sultan Suleiman I carried out the mining reform, which contributed to the recovery of a number of mines and the opening of new mines. However, for some mines, such as for example Zaplana it took more than half a century to restore the former production, and one of the reasons was safety in the mine (Katić, 2009, 74).

Exploitation of Prloš mine, as well as other Ottoman mines, was leased out. In the $15^{\text {th }}$ and most of the $16^{\text {th }}$ Century, mine leases were paid in cash and lasted for three years. ${ }^{18}$ Only from the end of the 1580's began domination of the leases which were calculated in kind, or in metal, while the lease term was extended to six years. Leases in kind were related only to the production of mines, while the revenues from mining hâsses were always calculated in cash (Katić, 2010, 111).

In the first few decades of the $16^{\text {th }}$ Century, tenants of the revenues mines and hâsses of Prloš were three Christians and two Muslims. The largest debt among the tenants in Prloš had Jovan's son Ilija from the village of Prlina which belonged to the jurisdiction of Novo Brdo, for part of the income of Prloš and Mehane mines. ${ }^{19}$ This debt for a three-year rent with taxes and installments was recorded on 28 June 1532. Of this,

\footnotetext{
${ }^{18}$ About the leases in the Ottoman Empire, see: L. T. Darling, Revenue-Raising and Legitimacy, Tax Collection and Finance Administration in the Ottoman Enmpire 1560-1660, Leiden - New York - Köln 1996; S. Katić, „Zakup rudnika i hasova Trepče 1585. godine“, Mešovita građa (Miscellanea) XXXI, Beograd 2010, 111.

${ }^{19}$ Today the village of Mehane, north of Mount Majdan.
} 
156 recorded as the debt of emin Mehmed from the income of Mehane mine, and the rest as the debt of the aforementioned tenant of 126.283 akches (BOA, MAD 656, s. 298-299). ${ }^{20}$

Lease of mukâta' $a$ of hâss of Prloš from 11 March 1574, for three years, amounted to 386.000 akches (BOA, MAD 654, s. 248). The same mukâta' $a$ was leased out on 11 March 1578 for the amount of 396.000 akches (BOA, MAD 654, s. 244).

In the second half of the $16^{\text {th }}$ Century, the dominance of Muslims in leasing operations in relation to Christians is noticeable. Mukâta ' $a$ of hâsses of Prloš was issued on 11 November 1584, for three years, for the amount of 346.000 akches (BOA, MAD 6148, s. 26). Müfettiş-inspector who was in charge of mukâta ' $a$ of hâsses of Prloš mines, Bıyıklı Mustafa, was also in charge of rice fields on the rivers around Niš, mevkufât $t^{21}$ of Kruševac Sancak, Kruševac scale, Majdanpek mine, Kučajna mint, as well as new revenues of Kučajna. All these mukâta 'as were registered on 17 April 1583 as the responsibility of Mevlânâ Muslihudin, the kâdî of Belgrade (BOA, MAD 6148, s. 106).

At the end of the $16^{\text {th }}$ Century, Keyvan, a kethüd $\hat{a}^{22}$ from the mahalle of the Yakub's Mosque in Belgrade appears as the tenant of Prloš. Pursuant to sicil of the kâdî of Belgrade, Mevlânâ Omer, müfettiş of mukâta 'a, he took the mukâta ' $a$ of the hâsses of Prloš and its surroundings under six year lease on 10 October 1587. This mukâta ' $a$ was united with the mukâta' $a$ of the hâsses of Sefer-Ağa and emîn of the mine in Kruševac Sancak, which was taken under lease starting from 10 April 1586. The total rent for both mukâta 'as for six years amounted to 1,490,324 akches. This was at the same time the amount of the equity. The condition was not to separate the mukâta 'as. Salaries of the people employed on mukâta' $a$ were supposed to be paid from tahvîl-lease. ${ }^{23}$ Seven people guaranteed for this lease with their property. One of the guarantors was the son of tenant Keyvan, Mustafa, who performed the function of the scribe of mukâta' $a$ of Prloš for a salary of 14 akches. A berât was issued to the said tenant, approving this lease (BOA, DBŞM 102, s. 2-3).

The hâss that carried the name of Prloš remained until the $18^{\text {th }}$ Century. In 1708, the old income of the mukâta' $a$ of Prloš was registered

\footnotetext{
${ }^{20}$ In the 1520 's, tenants in Rumelia were facing problems related to payment of assumed obligations, and some of them ended up in jail. Main causes of disturbances in financial operations were the above mentioned outbreaks of plague and mass migrations of the population to the newly conquered areas (Katić, Katić, 2010, 220-221).

${ }^{21}$ This was the term denoting money, income from empty tîmârs, surplus of vaqf revenues that belonged to the imperial treasury, customary costs, as well as everything that belongs to the funds used to finance warfare (Pakalın, 1993, 497; Sertoğlu, 1986, 223).

${ }^{22}$ Administrator of affairs.

${ }^{23}$ A technical term, meaning the time of lease, i.e. time of enjoyment of lease of a certain mukâta ' $a$; the period in which the tenant has the right to enjoy the leased revenues.
} 
in the amount of $1,787.5$ grosz, with a remark that this mukâta ' $a$ had not been on sale for the past three-four years and that state offices had not have income from it (Katić, 2005a,13). ${ }^{24}$

Table 1 The number of taxpayers in the settlements that belonged to Medveđa in the $16^{\text {th }}$ Century ${ }^{25}$

\begin{tabular}{|c|c|c|c|c|c|c|c|c|c|c|c|c|c|c|c|c|c|c|c|c|}
\hline \multirow[b]{2}{*}{$\begin{array}{l}\text { Name of the } \\
\text { settlement }\end{array}$} & \multicolumn{5}{|c|}{1516.} & \multicolumn{4}{|c|}{1530.} & \multicolumn{5}{|c|}{1536.} & \multicolumn{6}{|c|}{1570.} \\
\hline & âne & $\mathrm{m}$. & & & & & & & & & & 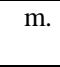 & & & & & & & M. & \\
\hline Bradošor & 20 & 4 & 1 & - & - & 16 & 4 & - & - & - & 20 & 4 & - & - & 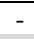 & 9 & - & - & - & \\
\hline & 40 & 10 & 2 & - & - & 38 & 9 & 1 & - & 1 & 29 & 4 & - & - & 1 & 22 & - & - & - & \\
\hline Crvo & 41 & 13 & 4 & - & - & 36 & 10 & 3 & - & 3 & 30 & 3 & - & - & & 37 & 7 & - & & \\
\hline D. G & 41 & 12 & 6 & - & - & 45 & 9 & 6 & - & 1 & 35 & 5 & - & - & & 29 & - & - & - & \\
\hline & 36 & 6 & 4 & - & - & 30 & 10 & 2 & - & 3 & 17 & 6 & - & - & 1 & 12 & - & - & - & \\
\hline D..$\check{S}$ & 91 & 18 & 10 & 3 & - & 60 & 18 & 7 & 1 & 2 & 36 & 4 & - & - & 1 & 26 & - & - & - & \\
\hline & 36 & 8 & 3 & 1 & 1 & 45 & 6 & 3 & - & 1 & 30 & 5 & - & - & & 34 & 4 & - & - & \\
\hline & 22 & 4 & 4 & - & - & 13 & 5 & 1 & - & 2 & 19 & 6 & - & - & & 8 & - & - & - & \\
\hline $\begin{array}{l}\text { G } \\
\text { (I }\end{array}$ & 41 & 10 & 1 & - & - & 45 & 11 & 2 & - & - & 26 & 5 & - & - & - & 30 & 5 & - & - & \\
\hline & 45 & 12 & 3 & - & - & 50 & 11 & 4 & - & - & 29 & 5 & - & - & - & 24 & - & - & - & \\
\hline & 6 & 7 & 2 & 4 & - & 52 & 16 & 6 & - & 3 & 44 & 11 & - & 6 & 1 & 34 & 3 & & 21 & \\
\hline & 29 & 7 & 2 & 3 & - & 28 & 6 & 4 & - & 3 & 16 & 2 & - & - & 2 & 12 & - & & 2 & \\
\hline & 22 & 4 & 3 & 2 & - & 25 & 1 & 4 & - & - & 24 & 2 & - & - & - & 21 & 1 & - & - & \\
\hline & 1 & 2 & 2 & - & 1 & 10 & 4 & 1 & - & 1 & 12 & 2 & - & - & - & 10 & 1 & - & - & \\
\hline Kral & 24 & 5 & 2 & - & 1 & 26 & 5 & 2 & - & 1 & 23 & 2 & - & 1 & 1 & 11 & - & - & - & \\
\hline & 5 & 15 & 1 & - & - & 60 & 12 & 2 & - & - & 40 & 13 & - & - & - & 51 & 1 & - & - & \\
\hline & 7 & 15 & 9 & 2 & - & 55 & 21 & 10 & 3 & 1 & 62 & 6 & - & 6 & 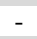 & 36 & 2 & & 37 & \\
\hline Oražc & 65 & 13 & 7 & - & - & 68 & 11 & 8 & - & 1 & 59 & 10 & - & - & - & 41 & 1 & - & - & \\
\hline $\begin{array}{l}\text { Orač } \\
\text { (Orašince) }\end{array}$ & 60 & 15 & 7 & - & - & 63 & 10 & 7 & - & 1 & 50 & 7 & - & - & 1 & 24 & - & - & - & \\
\hline & & 2 & 2 & - & - & 10 & 5 & 1 & - & - & 16 & 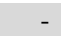 & - & - & 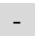 & 17 & - & - & - & \\
\hline & 2 & 5 & 1 & - & - & 28 & 5 & 1 & - & - & 26 & 3 & - & - & - & 24 & - & - & - & \\
\hline & 51 & 8 & 6 & - & - & 47 & 9 & 5 & - & 1 & 46 & 10 & - & - & - & 33 & - & - & - & \\
\hline TOTAL & 905 & 195 & 82 & 15 & 3 & 850 & 198 & 80 & 4 & 25 & 689 & 115 & -1 & 13 & 8 & 545 & 25 & & 60 & \\
\hline $\begin{array}{l}\text { Number of } \\
\text { all taxpayers }\end{array}$ & & & & & & & & & & & & 817 & & & & & & & & \\
\hline
\end{tabular}

\footnotetext{
${ }^{24}$ Because of the lack of diacritical points, R. Tričković read the name of this mukâta ' $a$ as Trebuš (Tričković, 1977, 263).

${ }^{25} \mathrm{~m}$. - mücerred, bi-bive, M.-Muslim, b.-baştine
} 


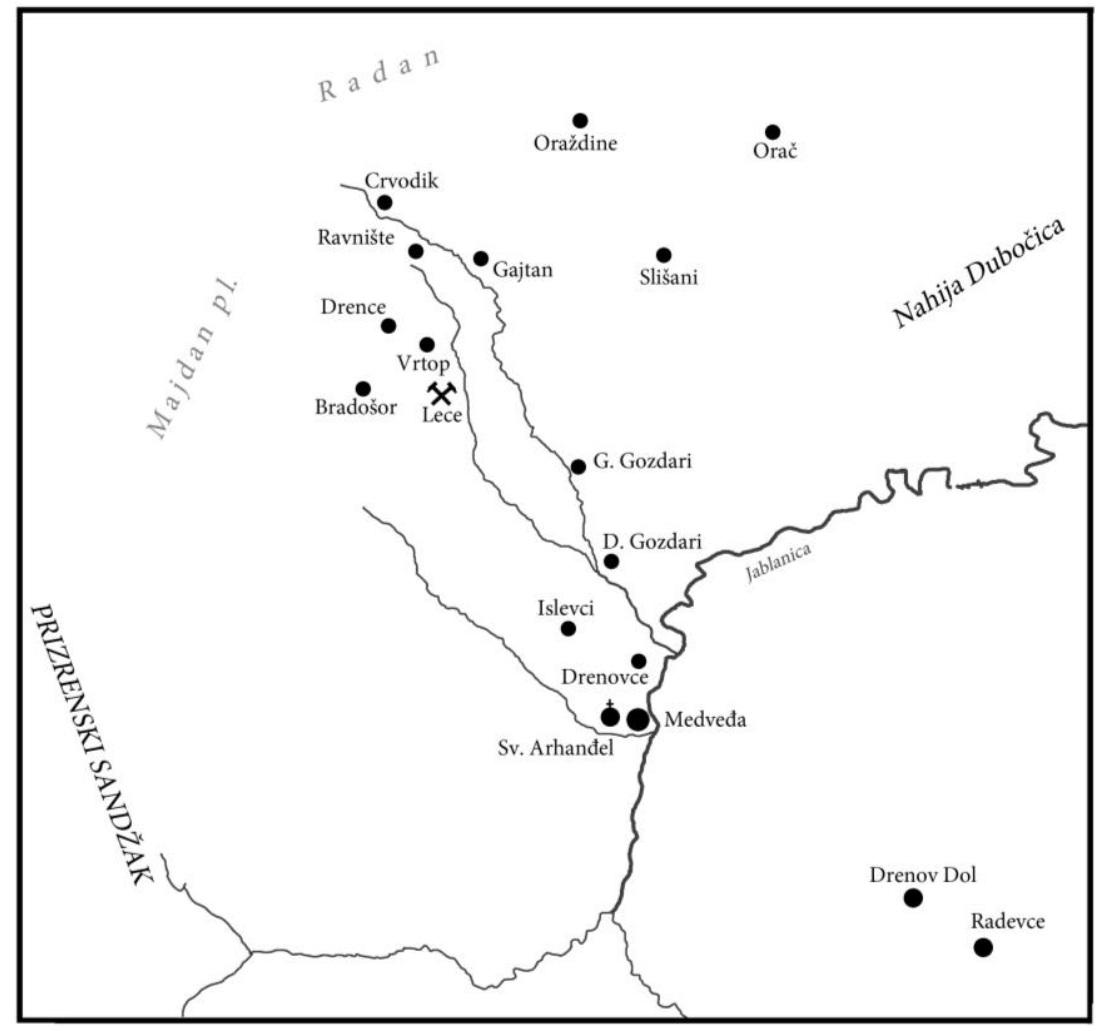

Map 1 Settlements that belonged to the hâss of Prloš mine $e^{26}$

$* * *$

On the basis of the above, we can conclude that Prloš was a mine that was worth the attention and investment for the Ottoman administration, given that a workers' hâss and the status of an independent mukâta ' $a$ was assigned to it. These are conditions that only about thirty mines in Rumelia had (Katić, 2015, 17). At the end of the $16^{\text {th }}$ Century, Prloš mine loses the status of an independent mukâta' $a$ and is merged with other mukâta 'as.

We cannot say with certainty until when this mine remained, but it is known that at the beginning of the $18^{\text {th }}$ Century its hâss was still there and was maintained, although this mukâta ' $a$ was no longer leased out and the state no longer had revenues from it.

${ }^{26}$ The villages of Prloš, Drenovce, Selce and Ludopare, which we have not located, also belonged to the hâss. 


\section{REFERENCES}

167 numaralı muhâsebe-i vilâyet- Rûm-ili defteri (937/1530), II, Vılçııtrın, Prizrin, Alaca-hisâr ve Hersek Livâları, (Dizin ve Tipkıbasım), Başbakanlık Devlet Arşivleri Genel Müdürlüğü, Osmanlı Arşivi Daire Başkanlığı Yayın Nu: 69, Defter-i Hâkânî Di-zisi: IX, Ankara 2004.

Akgündüz, A. (1990). Osmanl kanunnameleri ve hukuki tahlilleri, 2. kitap II Bâyezid devri kanunnâmeleri, Istanbul : Fey Vakfi.

Başbakanlık Osmanlı Arşivi Istanbul [hereinafter: BOA]: Maliye defteri - Maliyeden müdevver defteri, [MAD] 656, MAD 654, MAD 6148, BOA, Bab-i defteri, Baş muhasebe kalemi, [D.BŞM]102, Tapu tahrir defterleri, [TD] 55, 179, 664.

Beldiceanu, N. (1964). Les Actes des premiers sultans conservés dans les manuscrits turcs de la Bibliothéque natıonale à Paris, II, Paris - La Haye : Mouton\&Co.

Blanchard, I. (2005). Mining, Metallurgy and Minting in the Middle Ages, Vol. 3. Continuing Afro-European Supremacy, 1250-1450, Stuttgart : Stainer.

Bojanić, D. (1974). Turski zakoni i zakonski propisi iz XV i XVI veka za Smederevsku, Kruševačku $i$ Vidinsku oblast [Turkish laws and legal regulations from the 15th and 16th centuries for the Smederevo, Krusevac and Vidin regions], Beograd: Istorijski institut.

Bojanić, D. (1985). Jadar u XVI i XVII veku [Jadar in the XVI and XVII century], Loznica u prošlosti [Loznica in the past], Loznica, 77-190.

Božanić, S. (2007). Razvoj rudarstva i trgovina plemenitim metalima u manjim kopaoničkim rudnicima u srednjem veku [Development of mining and trade of precious metals in smaller Kopaonik mines in the Middle Ages], PanonijaBalkan-Sredozemlje, Novi Sad: Vojvođanska akademija nauka i umetnosti.

Ćirković, S. (1997). Rabotnici, vojnici, duhovnici [Workers, soldiers, clerics], Beograd: Equilibrium.

Ćirković, S., Kovačević-Kojić, D. \& Ćuk, R. (2002). Staro srpsko rudarstvo [Old Serbian mining], Beograd - Novi Sad: Vukova zadužbina - Prometej.

Darling, L. T. (1996). Revenue-Raising and Legitimacy, Tax Collection and Finance Administration in the Ottoman Enmpire 1560-1660, Leiden - New York Köln: Brill.

Dinić, M. (2003). Iz srpske istorije srednjeg veka [From Serbian medieval history], Beograd: Equilibrium.

Dušanić, S. (2003). Roman mining in Illyricum: Historical aspects, Dall' Adriatico al Danubio-L'Illirico nell'età greca e romana, Atti del convegno internazionale, Cividale del Friuli, 25-27 settembre 2003, Pisa: Edizione Elettronica, 247-270.

Handžić, A. (1974). Najraniji turski izvori o rudnicima i trgovima u Bosni [The earliest Turkish sources on mines and squares in Bosnia], Prilozi Instituta za istoriju, god XII, br. 10/2, Sarajevo, 155-162.

Handžić, A. (1976). Rudnici u Bosni u drugoj polovini XV stoljeća [Mines in Bosnia in the second half of the XV century], Prilozi za orijentalnu filologiju XXVI, Sarajevo 1978, 7-42.

Ilić, N. P. (1984). Rudnik Lece [Lece mine], Leskovac: Narodni muzej u Leskovcu.

İnalc1k, H. (2000). Osmanl Imparatorluğu'nun Ekonomik ve Sosyal Tarihi, Cilt 1 (1300-1600), İstanbul : Eren Yayınları.

İnalcık, H. (2002). Osmanlı Para ve Ekonomi Tarihine Toplu Bir Bakış, Doğu Batı, sy. 17, Ankara, s. 9-33.

Ivanišević, V. \& Bugarski, I. (2017). Program novih istraživanja Caričinog grada [Program of new researches of the Caričin grad], Leskovački zbornik 57, 51-62. 
Jocić, M. (1999). Rezultati rekognosciranja Gornje Jablanice [Results of the reconnaissance of Gornja Jablanica], Leskovački zbornik XXXIX, Leskovac, $50-54$.

Jovanović, B. (2005-2006). Arehometalurška nalazišta - nova kategorija kulturnih dobara [Arehometalurška sites - a new category of cultural goods], Saopštenja 37-38, 211-216.

Jovanović, B. (1988). Prljuša - Mali Šturac, Praistoriski rudnik bakra i gorskog kristala na Rudniku [Prljuša - Mali Šturac, Prehistoric mine of copper and rock crystal on Rudnik], Zbornik radova Narodnog muzeja u Čačku 18, 5-12.

Jovanović, B., Minić, D. \& Mrkobrad, D. (1987). Spomenici starog rudarstva i metalurgije na Rudniku [Monuments of ancient mining and metallurgy in Rudnik], Glasnik SAD 4, 47-54.

Katić, S. (2001). Uloga Jevreja u otvaranju i razvoju rudnika Kučajna i Majdanpek u drugoj polovini XVI veka [The role of Jews in the opening and development of Kučajna and Majdanpek mines in the second half of the 16th centuries], Godišnjak za društvenu istoriju, VIII/1-2, 7-17.

Katić, S. (2005a). Popis prihoda beogradske kancelarije iz 1708. godine [Census of revenues of Belgrade office from the year 1708], Mešovita građa (Miscellanea) XXIV, 7-16.

Katić, S. (2005b). Istorija rudarstva i metalurgije u Osmanskom carstvu (na primeru smederevskog sandžaka) [History of Mining and Metallurgy in the Ottoman Empire (the case of Smederevo Sancak] Beograd (Doctoral dissertation).

Katić, S. (2007). Rudnik pod osmanskom vlašću u XV i XVI veku [Rudnik under the Ottoman rule in the XV-XVI centuries], Istorijski časopis LV, 133-155.

Katić, S. (2009). Stvaranje martoloskih odreda u kopaoničkim rudnicima Plana, Zaplana i Belasica [Creating of martolos units in the Kopaonik mines Plana, Zaplana and Belasica], Krušsevački zbornik 13, Kruševac, 73-77.

Katić, S. \& Katić, T. (2010). Rudnik Žežna i rudarstvo Rogozne i Podbukovika u 16. veku [The Žežna mine and mining of Rogozna and Podbukovik in the XVI century], Istorijski časopis, knj. LIX, 197-224.

Katić, S. (2010). Zakup rudnika i hasova Trepče 1585. godine [Lease of the Trepča mine and hâss in the year 1585], Mešovita građa (Miscellanea) XXXI, Beograd 109-121.

Katić, S. (2015). Rudarstvo Čemerna i Troglava (16-17. vek) [Mining at Čemerno and Troglav $\left(16^{\text {th }}-17^{\text {th }}\right.$ centuries) ], Naša prošlost $16,9-24$.

Neşri, M. (1987). Kitâb-i Cihannümâ, Neşri Tarihi, F. R.Unat ve M. A. Köymen, Ankara : Türk Tarih Kurumu.

Pakalın, Zeki M. (1993). Osmanlı Tarih Deyimleri ve Terimleri Sözlü̆̆̈̈ II, Istanbul : Milli Eğitim Basımevi.

Pamuk, S. (2000). A Monetary History of the Ottoman Empire, London : Cambridge University Press.

Petrović, V. (2014). Društvena i prostorna struktura srpskih gradskih naselja u poznom srednjem veku [Social and spatial structure of Serbian urban settlements in the late Middle Ages], Beograd (Doctoral dissertation).

Petrović, V. (2015). Zaplanina, Kopaonik, Beograd : Službeni glasnik : Geografski institut „Jovan Cvijić” SANU : Nacionalni park Kopaonik, 67-68.

Petrović, V. (2015). Plana, Kopaonik, Beograd : Službeni glasnik : Geografski institut „Jovan Cvijić” SANU : Nacionalni park Kopaonik, 147-148.

Popović, T. (1994). „Privreda u XVI i XVII veku”, ISN III/1, Beograd : Srpska književna zadruga, 575-645.

Refik, A. (1931). Osmanlı devrinde Türkiye madenleri (967-1200), Istanbul : Devlet Matbaas1. 
Rizaj, S. (1968). Rudarstvo Kosova i susednih krajeva od XV do XVII veka [Mining of Kosovo and neighboring regions from the 15th to the 17th century], Priština : Zajednica naužnih ustanova Kosova i Metohije.

Sertoğlu, M. (1986). Osmanli Tarih Lûgatı, Istanbul : Enderun Kitabevi.

Simić, V. (1974). Prilog za poznavanje naše starije terminologije u rudarstvu [Contribution to the knowing of our older terminology in mining], Zbornik radova XVI, Bor, Rudarsko-geološko-metalurški institut za bakar u Boru, 147-190.

Simić, V. (1951). Istorijski razvoj našeg rudarstva [Historical development of our mining], Beograd : Izdavačko-štamparsko preduzeće Saveta za energetiku i ekstraktivnu industriju Vlade FNRJ.

Spaho, F. (1913) Turski rudarski zakoni [Turkish Mining Laws], Glasnik Zemaljskog muzeja Bosne i Hercegovine, vol. XXV (1913), 133-194.

Škrivanić, G. (1974). Putevi u srednjevekovnoj Srbiji [Roads in the medieval Serbia], Beograd : Turistička štampa.

Tričković, R. (1977). Beogradski pašaluk 1687-1739. godine [Belgrade pashaluk 1687-1739. years], Beograd (Doctoral dissertation).

Vasić, M. (1980). Sumarni defter sandžaka Aladža Hisar (Kruševac) iz 1516. godine kao istorijski izvor [Summary census of Aladža Hisar (Kruševac) Sancak from 1516 as a historical source], Prilozi za orijentalnu filologiju 28-29 (1978-79), Sarajevo, 331-356.

Zarković, B. (2017a). Trgovi i urbanizacija Srbije u srednjem veku [Marketplaces and urbanization in Serbia in the Middle Ages], Kosovska Mitrovica: Filozofski fakultet Univerziteta u Prištini sa privremenim sedištem u Kosovskoj Mitrovici.

Zarković, B. (2017b). Ostatija ili Ostraća [Ostatija or Ostraća], Zbornik radova Filozofskog fakulteta u Prištini sa privremenim sedištem u Kosovskoj Mitrovici LXVII (2), 169-193.

Zirojević O. \& Eren, I. (1968). Popis oblasti Kruševca, Toplice i Dubočice u vreme prve vladavine Mehmeda II (1444-1446) [Census of Kruševac, Toplica and Dubočica area during the first reign of Mehmed II (1444-1446)], Vranjski glasnik 4 (1968), 377-416.

Zirojević, O. (1983). Leskovac i njegova nahija od 1445. do 1683. godine [Leskovac and its nâhiye from 1445 to 1683], Leskovački zbornik 23, 211-268.

\title{
РУДАРСТВО У ДУБОЧИЦИ У 16. ВЕКУ
}

\author{
Драгана Амедоски, Владета Петровић
}

Историјски институт Београд, Београд, Србија

\section{Резиме}

Област данашње Србије има изузетно дугу традицију рударства. Средњовековна рударска производња у Србији је свој врхунац достигла у првој половини 15. века. Богати рудници злата и сребра и значајни трговачки центри постали су примарни циљеви у Портиним освајачким плановима. Почев од времена Мурата I (1359-1389), Османлије преузимају контролу над појединим богатим рудницима у Србији и Босни. Циљ Османлија био је максимално искоришћење ових рудника како би одговорили на своје потребе за драгоценим металима, гвожђем и оловом. Са 


\section{0}

ширењем османске власти на јужне области српске средњовековне државе, под њену контролу доспева богата рударска регија Копаоника, рејон Плане, Заплане и слишански (јабланички) рејон. Један њен део припао је Крушевачком санџаку. У рејону Плане и Заплане настављена је рударска активност и након османских освајања. У османско доба, на територији Крушевачког санџака, у нахији Дубочица, ближе Медвеђи, функционисао је још један рудник о коме није писано у домаћој историографији. Његово име је неизвесно због непрецизности арапског писма; неке од варијатни су Прлош, Перлош, Пирлош, Прелош, Прелуш, Прлуш. Самм рудник носио је исто име као и једно село које је данас непознато. Међутим, до данас се није задржао ниједан топоним који би нам указао на место рудника и села. Овај рудник не помињу ни путописци, што наводи на закључак да се није налазио на некој од оближњих главних саобраћајница. Очигледно је да је рудник Прлош почетком 16. века био прилично значајан јер је око њега формиран раднички хас. Према попису из 1599/1600. године, хасу рудника Прлош припадала су 22 села и један манастир. Рудник Прлош се вероватно налазио у границама свог хаса, чија су села већином припадала Медвеђи. Стога би га требало тражити на простору између планина Радан, Мајдан и Расовача. Како се на овом подручју данас налази активни рудник олова и цинка Леце, стари рудник Прлош можемо везати за пространи рударски рејон који се простире од Новог Брда до Ђавоље вароши. Становништво села на хасу било је већином хришћанско. Током 16. века у селима хаса Прлош дошло је до изразитог демографског пада који је износио 47,1 \%. Експлоатација рудника Прлош, као и осталих османских рудника, давана је у закуп. Хас који је носио име Прлош одржао се све до 18. века. 